\title{
Financial Report of Zakat Institutions: Guidelines and Accounting Standard
}

Nur Afiqah Bakri, Wan Anisah Endut, Suraya Ismail, Roshaiza Taha

To Link this Article: http://dx.doi.org/10.6007/IJARBSS/v12-i1/11468

DOI:10.6007/IJARBSS/v12-i1/11468

Received: 05 November 2021, Revised: 06 December 2021, Accepted: 29 December 2021

Published Online: 05 January 2022

In-Text Citation: (Bakri et al., 2022)

To Cite this Article: Bakri, N. A., Endut, W. A., Ismail, S., \& Taha, R. (2022). Financial Report of Zakat Institutions: Guidelines and Accounting Standard. International Journal of Academic Research in Business and Social Sciences, 12(1), 65-75.

\section{Copyright: @ 2022 The Author(s)}

Published by Human Resource Management Academic Research Society (www.hrmars.com)

This article is published under the Creative Commons Attribution (CC BY 4.0) license. Anyone may reproduce, distribute, translate and create derivative works of this article (for both commercial and non0-commercial purposes), subject to full attribution to the original publication and authors. The full terms of this license may be seen at: http://creativecommons.org/licences/by/4.0/legalcode

\section{Vol. 12, No. 1, 2022, Pg. $65-75$}

Full Terms \& Conditions of access and use can be found at http://hrmars.com/index.php/pages/detail/publication-ethics 


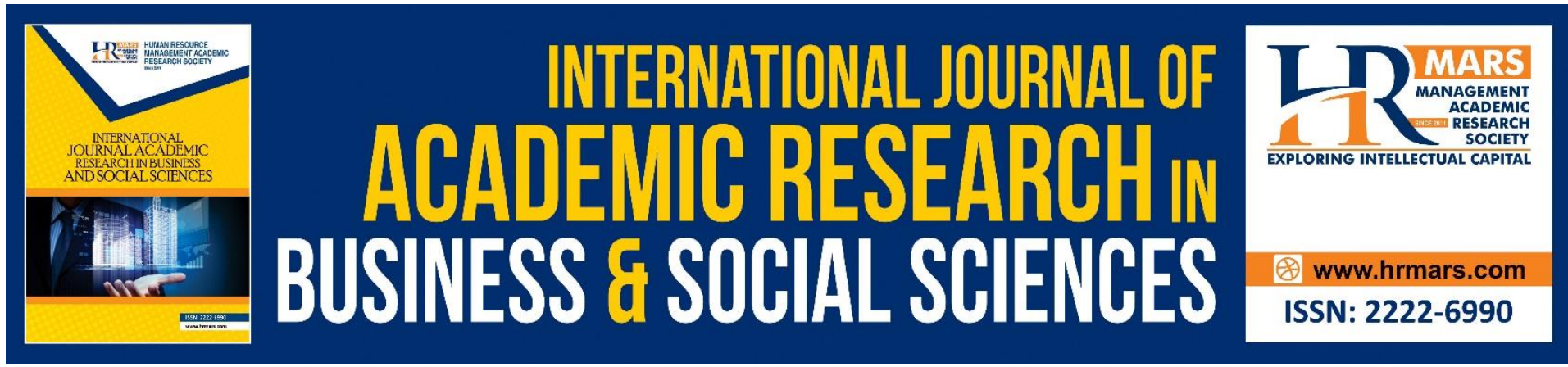

\title{
Financial Report of Zakat Institutions: Guidelines and Accounting Standard
}

\author{
Nur Afiqah Bakri, Wan Anisah Endut, Suraya Ismail
}

Faculty of Business and Management, Universiti Sultan Zainal Abidin (UniSZA) Malaysia

Email: nurafiqah958@gmail.com.my, surayaismail@unisza.edu.my

Roshaiza Taha

Faculty of Business, Economics and Social Development, Universiti Malaysia Terengganu

Email: roshaiza@umt.edu.my

Corresponding Author Email: wanisah@unisza.edu.my

\begin{abstract}
Zakat is a Shariah mechanism that aims to achieve social justice, especially from an economic point of view. The purpose of establishing a zakat institution in a country is to manage activities related to the collection and distribution of zakat. In addition, zakat institutions also need to prepare financial reports. The preparation of financial reports is to disclose important information and activities of zakat institutions to stakeholders. The question now is, what are the accounting guidelines or standards used or referred to in preparing these reports? Thus, this paper tries to identify which guidelines or accounting standards are used or referred to in preparing financial reports by zakat institutions in two ASEAN countries, namely Malaysia and Indonesia. Based on the content analysis method, the findings show that both countries' accounting bodies or governments have issued guidelines or accounting standards to ensure adequate disclosures by zakat institutions. Although there are guidelines or standards, the findings showed that some zakat institutions do not fully comply with the standards or guidelines in preparing financial reports for their institutions.
\end{abstract}

Keywords: Financial, Reporting, Zakat, Guidelines, Standard

\section{Introduction}

Zakat is one of the important acts of worship in Islam. Zakat functions to solve economic issues by alleviating poverty (Hasibuan, 2016), specifically in Muslim-dominated countries (Bala et al., 2019). Therefore, zakat institutions have been established to improve zakat collection and utilisation to promote public welfare and poverty reduction (Sudirman et al., 2019). While, financial reporting is central to illustrate how organisational transparency and accountability information are disclosed to the public (Ali et al., 2020; Roslan et al., 2017). Specifically, the information disclosure function to communicate to the public organisational performance and activities (Kamaruddin, 2018).

The existence of financial reporting convinces and builds assurance concerning organisational money management, particularly entrusted in zakat institutions; financial 
reporting typically functions as evidence of accuracy and well-management (Kamaruddin \& Ramli, 2018; Sarif et al., 2015). However, the efficiency of zakat institutions in zakat management is often disputed by the public. Transparency and accountability of financial reporting across zakat institutions have often been associated with the dispute (Pamuncak et al., 2018). Previous studies found that there was insufficient financial disclosure information reporting (Abdullah, 2012; Abdullah \& Razak, 2015; Nikmatuniayah et al., 2017; Wahid et al., 2017). Fully disclosed financial reporting information could reduce negative perceptions towards zakat institutions (Taha et al., 2015).

Not only do zakat institutions prioritise financial information, but zakat institutions also need to communicate to the public non-financial information, particularly zakat activities, to provide information concerning where and how zakat funds are used (Endut et al., 2020). First, financial reporting is seen as a mechanism to disclose financial and nonfinancial information of zakat institutions to bolster accountability to the public (Masruki et al., 2018b; Roslan et al., 2017). Second, transparency is essential to generate public trust in zakat institutions (Nurhayati et al., 2014). Therefore, financial information disclosure is imperative to enhance trust and hinder negative perceptions on zakat management across zakat institutions (Samargandi et al., 2018).

This study aims to identify the guidelines or accounting standards are used or referred to in the preparation of financial reports by zakat institutions in two ASEAN countries, namely Malaysia and Indonesia. ASEAN countries which were established in 1967 consisted of ten nations, namely Indonesia, Malaysia, Philippines, Singapore, Brunei, Vietnam, Cambodia, Laos, and Myanmar. Only two ASEAN countries, Indonesia and Malaysia were the focus of the current study firstly due to the Muslim-dominant country status and secondly, due to the similar cultural settings. Therefore, the review concerning the two ASEAN countries attempted to highlight the issues concerning zakat financial reporting.

This paper is divided by four sections. First, a section on methodology is presented. Second, the zakat management discussion in Indonesia and Malaysia is presented to demonstrate zakat administration understanding while the third section presented the financial accounting standards or guidelines across zakat institutions. Also, financial reporting issues among zakat institutions are provided based on data analysis. Finally, the conclusion of the review is provided.

\section{Methodology}

A qualitative method was used to analyse financial reporting standards and guidelines in Indonesia and Malaysia. Journals, books, annual reports, and websites emphasising zakat institutions in the respective countries were analysed. Content analysis was used to identify financial reporting standards or guidelines including financial reporting-related issues that were prevalent across zakat institutions.

\section{Zakat Management in Malaysia and Indonesia}

Zakat institutions were established to administer the disbursement and collection of zakat to ensure stability and socioeconomics (Ahmad et al., 2015). Therefore, Indonesia and Malaysia established an official zakat institution that manages zakat collection and distribution. In Indonesia, the government established National Board of Zakat (BAZNAS) which has the task and function of collecting and distributing zakat, infaq, and sadaqah at the national level. While, Amil Zakat Institution (LAZ) were formed by the community and is tasked with assisting BAZNAS in managing Zakat activities (Irti \& Susanto, 2019). Zakat Act Law No. 23 in 2011 
concerning Zakat Management Organisation that was issued by the Indonesian government emphasise the organisational activities in planning, implementing, and coordinating zakat collection, distribution, and utilisation (Fathony \& Fatimah, 2017).

Meanwhile, Malaysian zakat falls under the state jurisdiction that is accorded the authority to manage the organisations by complying with the Federal Constitution Ninth Schedule, namely, the State Islamic Religious Council (SIRCs). Only Kuala Lumpur, Labuan, and Putrajaya fall under federal jurisdiction. In 2004, the federal government established the Waqf, Zakat, and Hajj Department (JAWHAR) to coordinate the administration of all Malaysian zakat institutions (Mansor et al., 2017). JAWHAR serves to plan, implement, monitor, and coordinate the need to standardise legal systems of zakat, waqf, Baitul mal, and hajj institutional development. By focusing on the legal systems, effective zakat administration could serve the ummah's socio-economic development.

Several SIRCs are privatise zakat administration for effective and efficient zakat collection (Ali et al., 2017). Some zakat institutions privatised both zakat collection and distribution, as could be seen across Selangor, Pulau Pinang, and Sarawak. Other states, for example, Wilayah Persekutuan, Negeri Sembilan, Pahang, and Melaka, simply privatised zakat institutions in terms of zakat collection (Hamid \& Jusoh, 2016; Islam \& Salma, 2020). Consequently, the structure of Malaysian zakat management activities changed in certain states. All states operated within sets of acts or enactments in managing zakat collection and distribution (Abu Bakar, 2007). Overall, Malaysian zakat institutions complied with different zakat administration systems as specified in the enactments and acts that were issued gradually in the respective states. Table 1 lists the 14 State Enactment according to State Administration. 
Table 1: The list of State Enactment in respective states

\begin{tabular}{|c|c|}
\hline States & Enactments \\
\hline Selangor & $\begin{array}{l}\text { Administration of The Religion of Islam Selangor } \\
\text { Enactment } 2003\end{array}$ \\
\hline Pulau Pinang & $\begin{array}{l}\text { Administration of The Religion of Islam Pulau Pinang } \\
\text { Enactment } 2004\end{array}$ \\
\hline Sarawak & Majlis Islam Sarawak Ordinance 2001 \\
\hline $\begin{array}{c}\text { Wilayah } \\
\text { Persekutuan }\end{array}$ & $\begin{array}{l}\text { Administration of Islamic Law (Federal Territories) } \\
\text { Act } 1993\end{array}$ \\
\hline Negeri Sembilan & $\begin{array}{l}\text { Administration of The Religion of Islam Negeri } \\
\text { Sembilan Enactment } 2003\end{array}$ \\
\hline Melaka & $\begin{array}{l}\text { Administration of The Religion of Islam Melaka } \\
\text { Enactment } 2002\end{array}$ \\
\hline Pahang & $\begin{array}{l}\text { Administration of The Religion of Islam Pahang } \\
\text { Enactment } 1991\end{array}$ \\
\hline Terengganu & $\begin{array}{l}\text { Administration of The Religion of Islam Terengganu } \\
\text { Enactment } 2001\end{array}$ \\
\hline Kelantan & $\begin{array}{l}\text { Council of Islamic Religion and Malay Custom } \\
\text { Kelantan Enactment } 1994\end{array}$ \\
\hline Johor & $\begin{array}{l}\text { Administration of The Religion of Islam Johor } \\
\text { Enactment } 2003\end{array}$ \\
\hline Perlis & $\begin{array}{l}\text { Administration of The Religion of Islam Perlis } \\
\text { Enactment } 1964\end{array}$ \\
\hline Perak & $\begin{array}{l}\text { Administration of The Religion of Islam Perak } \\
\text { Enactment } 2004\end{array}$ \\
\hline Kedah & $\begin{array}{l}\text { Administration of Islamic Law Kedah Enactment } \\
2008\end{array}$ \\
\hline Sabah & $\begin{array}{l}\text { Administration of The Religion of Islam Enactment } \\
1992 \text { Sabah }\end{array}$ \\
\hline
\end{tabular}

Source: Zakariyah et al (2016)

\section{Guidelines and Accounting Standards for Zakat Institutions}

It was found that zakat was typically collected and disbursed by zakat institutional administration in Indonesia and Malaysia. While, financial reporting was used as a tool to convey information to the public concerning zakat activities to establish public confidence (Ebrahim, 2019). The financial reporting was found to have been used to facilitate stakeholders in the decision-making processes (Azar et al., 2019). A stakeholder is typically defined as a person that receives benefits from the proper organisational establishment and functions. Stakeholders could consist of a group of shareholders, investors, employees, suppliers, customers, and those that affect the businesses although the stakeholders are not engaged in business activities (Costa \& Da Silva, 2019; Galant, 2017). Thus, the organisational establishment as charitable organisations prepared financial reporting to accommodate a wide range of users (Cordery et al., 2019a). It was argued that a specific financial reporting framework and accounting standards were needed to bolster zakat institution functions to exercise and disclose accountability (Salleh et al., 2016). As such, zakat institutions were also responsible to function as trustees. 
In Indonesia, BAZNAS is mandated to submit financial reporting concerning regular zakat, infaq, alms, and miscellaneous socio-religious activity management (Hadijah, 2019). Furthermore, LAZ must make evident the accountability to prepare financial statements to demonstrate accurate bookkeeping as instructed by the Indonesian government (Nikmatuniayah et al., 2017). Thus, Indonesia Institute for Accountants (IAI) issued zakat, infaq, and alms standards, Statement of Financial Accounting Standards (PSAK No. 109) for Zakat Accounting (Hasibuan, 2016). PSAK No. 109 serves as a financial reporting guideline in zakat recognition, measurement, presentation, and disclosure (Irti \& Susanto, 2019). Furthermore, PSAK No. 109 is regulated to ensure uniformity in the preparation of zakat institution financial reporting. By focusing on financial reporting emphasising zakat, infaq, and alms, stakeholders' understanding is accommodated (Murniati \& Ikhsan, 2020).

Beside PSAK No. 109; Accounting for Zakat and Infaq/Shadaqah, Table 2 shows other references that are used as a reference in the preparation of this financial report (recognition measurement, presentation, and disclosure).

Table 2: Guidelines for Preparation of Financial Report for Zakat Institution: Indonesia

\begin{tabular}{|c|c|c|c|}
\hline $\begin{array}{r}\text { Financial } \\
\text { Accounting } \\
\text { Standards } \\
\text { (PSAK) } 109 \\
\text { Accounting for } \\
\text { Zakat and Infaq } \\
\text { (Shadaqah) }\end{array}$ & $\begin{array}{l}\text { - Law No. } 23 \text { of } 2011 \text { - } \\
\text { Zakat Management } \\
\text { - Government Regulation } \\
\text { No. } 14 \text { of } 2014 \text { - } \\
\text { Implementation of Law } \\
\text { no. } 23 \text { of } 2011 \\
\text { concerning Zakat } \\
\text { Management }\end{array}$ & $\begin{array}{l}\text { - Regulations related } \\
\text { to Zakat issued by } \\
\text { the Ministry of } \\
\text { Religion and } \\
\text { BAZNAS }\end{array}$ & $\begin{array}{l}\text { - Fatwa related } \\
\text { to zakat issued } \\
\text { by the } \\
\text { Indonesian } \\
\text { Ulema } \\
\text { Council; }\end{array}$ \\
\hline
\end{tabular}

Past studies on the application of Indonesian PSAK No. 109 accounting standards revealed the preparation of financial statements that illustrated BAZNAS and LAZ noncompliance to PSAK No. 109 (Arief et al., 2017; Shahnaz, 2015). When zakat financial statements were prepared in Indonesia, BAZNAS and LAZ should have implemented the PSAK No. 109 components that consisted of 1) Balance Sheet (Statement of Financial Position), 2) Report on Changes in Funds, 3) Report on Changes in Assets Under Management, 4) Statement of Cash Flows, and 4) Notes on Financial Statements (Muflihah \& Wahid, 2019). By preparing reports based on PSAK No. 109, BAZNAS and LAZ, the transparency and accountability could be presented to enhance public confidence (Megawati \& Trisnawati, 2014; Rahmadani et al., 2018). Furthermore, several zakat institutes, particularly BAZNAS Kotamobogu, BAZNAS Sulut, and LAZ Tasikmalaya, only published PSAK No. 109 selected components in financial reporting (Muflihah \& Wahid, 2019; Rahmadani et al., 2018; Shahnaz, 2015). BAZNAS Pekanbaru fully complied with PSAK No. 109 reporting standards (Megawati \& Trisnawati, 2014) while Baitul Mal Aceh recorded 94\% compliance with PSAK No. 109 standards in its reports (Murniati \& Ikhsan, 2020). Other studies which focused on the quality of Indonesian zakat institution financial reporting. An empirical study was conducted concerning financial reporting quality in the context of accounting information, accountability, and transparency. A positive and significant effect was recorded on simultaneous or partial levels of zakat fund acceptance (Nurhayati et al., 2014). Thus, the results demonstrated that the accounting information, accountability, and transparency qualities affected Indonesian zakat acceptance levels (Nikmatuniayah et al., 2017). 
The financial reporting framework that applies to zakat institutions generally depends on the legal form of the institutions. In Malaysia, most zakat administrators are State Islamic Religious Council (SIRCs). State zakat institutions have the autonomy to publish financial reporting (Taha et al., 2015). All SIRCs are mandated to submit financial report and will be audited by National Audit Department. Therefore, Malaysian government or Accounting Standards Board issued several accounting standards or guidelines that could be referred in preparing non-profit organisational or SIRCs financial reporting.

Table 3 lists among the accounting standards or guidelines as reference to SIRCs for preparing financial report which are States acts or enactments, Guidance on Best Practices in Financial Management (Amalan Terbaik Pengurusan Kewangan Majlis Agama Islam Negeri) issued by National Audit Department (Jabatan Audit Negara) in 2003, Malaysian Private Entities Reporting Standard (MPERS) as issued by Malaysian Accounting Standards Board (MASB) in 2009, Malaysian Public Sector Accounting Standards (MPSAS), as issued by Jabatan Akauntan Negara Malaysia (JANM) in 2017 and Manuals Zakat Calculation Management released by the Department of Awqaf, Zakat and Hajj (JAWHAR) in 2008.

Table 3: Guidelines for Preparation of Financial Report for Zakat Institution: Malaysia

\begin{tabular}{|l|l|l|l|}
\hline States acts or & $\bullet$ Guidance on Best & $\bullet$ Malaysian Private & - Malaysian Public \\
enactments in & Practices in Financial & Entities Reporting & Sector Accounting \\
managing zakat & Management & Standard (MPERS) & Standards (MPSAS) \\
collection and & (Amalan Terbaik & issued by the & issued by the \\
distribution & Pengurusan & Malaysian & Accountant \\
& Kewangan Majlis & Accounting & General's \\
Guidelines by & Agama Islam Negeri) & Standards Board & Department \\
Department of & issued by National & (MASB) & (Jabatan Akauntan \\
Awqaf, Zakat and & Audit Department & & Negara Malaysia) \\
Hajj (JAWHAR) & (Jabatan Audit & & \\
& Negara) & & \\
& & & \\
\hline
\end{tabular}

All Islamic affairs are managed by SIRC by complying with the State enactment including zakat, waqf, baitul mal, and masjid (Sarif et al., 2015). Unfortunately, the varying ways in which zakat is managed prompted public dissatisfaction and lack of assurance to Malaysian zakat institutions (Abu Bakar \& Rashid, 2010; Sapingi \& Nelson, 2016). One of the factors that could be associated with public dissatisfaction and lack of assurance was the low level of transparency disclosure (Taha et al., 2017).

Zakat practices in Malaysia are varies for each state, resulting in dissatisfaction with zakat transparency and accountability began to arise among the community. Thus, past studies had recommended adopting harmonised zakat practices to improve the transparency and accountability of zakat management, and so it would be well communicated (Muhammad, 2019; Taha et al., 2015). Urif (2015) claimed that the harmonisation would increase the agreement level in accounting standards and practices. Moreover, Lakmal (2014) also stated that harmonisation improves the compatibility of accounting practices by setting limits on how much they can vary.

\section{Conclusion}

It was found that official zakat institutions were established in Indonesia and Malaysia to manage zakat collection, distribution, and activities. Government or Accounting Standards 
Board from both countries issued several accounting standards or guidelines to ensure accountability and transparency institutions in the financial management of zakat. These standards or guidelines were established to standardise financial reporting across all zakat institutions. However, the findings indicate that there are differences in zakat financial reporting practices among zakat institutions.

\section{Acknowledgement}

This research was supported by the Ministry of Education (MOE) through Fundamental Research Grant Scheme (FRGS/1/2018/SS01/UNISZA/02/4).

\section{References}

Abdullah, R. (2012). Zakat Management In Brunei Darussalam:Funding The Economic Activities Of The Poor (First Edit, Issue December). Universiti Islam Sultan Sharif Ali.

Abdullah, R., \& Razak, A. L. A. (2015). Exploratory Research into Islamic Financial Literacy in Brunei Darussalam. Researchgate.Net, October, 28. https://doi.org/10.13140/RG.2.1.4815.1765

Abu Bakar, N. B. (2007). A Zakat Accounting Standard (ZAS) for Malaysian companies. American Journal of Islamic Social Sciences, 24(4), 74-92. http://irep.iium.edu.my/33857/

Abu Bakar, N. B., \& Rashid, H. M. A. (2010). Motivations of Paying Zakat on Income: Evidence from Malaysia. International Journal of Economics and Finance, 2(3), 76-84. https://doi.org/10.5539/ijef.v2n3p76

Ali, M. A. M., Tazilah, M. D. A. K., Shamsudin, A. I., Shukri, F. R. F., Adelin, N. M. F. A. N., \& Zaman, W. M. S. W. Z. (2017). Factors that Influence the Zakat Collection Funds: A Case in Kuantan. South East Asia Journal of Contemporary Business, Economics and Law, 13(1), 30-37.

Arief, S. W. H., Manossoh, H., \& Alexander, S. W. (2017). Analisis Penerapan Psak No. 109 Tentang Akuntansi Zakat, Infaq/Sedekah Pada Badan Amil Zakat Nasional Kota Manado. Going Concern : Jurnal Riset Akuntansi, 12(01), 98-107. https://doi.org/10.32400/gc.12.01.

Azar, N., Zakaria, Z., \& Sulaiman, N. A. (2019). The Quality of Accounting Information: Relevance or Value-Relevance? (Vol. 12, Issue 1, pp. 1-21).

Bala, M. J., Maiyaki, U. S., \& Farouk, H. (2019). the Statutory Principles of Zakat: an Effective Instrument for the Accomplishment of Economic Objectives in Kano State. International Journal of Advanced Academic Research / Arts, 5(6), 2488-9849.

Cordery, C. J., Crawford, L., Breen, O. B., \& Morgan, G. G. (2019). International practices, beliefs and values in not-for-profit financial reporting. Accounting Forum, 43(1), 16-41. https://doi.org/10.1080/01559982.2019.1589906

Costa, E., \& Goulart da Silva, G. (2019). Nonprofit accountability: The viewpoint of the primary stakeholders. Financial Accountability and Management, 35(1), 37-54. https://doi.org/10.1111/fa

Ebrahim, M. (2019). Financial Reporting for Islamic Financial Institutions. Islamic Finance Review, March, Pp. 52-53., October. https://doi.org/10.6084/m9.figshare.10067492

Fathony, A. A., \& Fatimah, I. (2017). Pengaruh Penerapan Psak 109 dan UU Nomor 23 Tahun 2011 Tentang Pengelolaan Zakat Terhadap Akuntabilitas Publik Di Lembaga Amil Zakat Pusat Zakat Umat Persis Bandung. 8(April), 10-21.

Galant, M. (2017). The Stakeholders Theory as A Starting Point for The Critique of Corporate 
Social Responsibility. Prace Naukowe Uniwersytetu Ekonomicznego We Wrocławiu, 464, 31-42. https://doi.org/10.15611/pn.2017.464.03

Hadijah, S. (2019). Analisis Penerapan PSAK 109 Tentang Akuntansi Zakat, Infaq, dan Sedekah pada Badan Amil Zakat Nasional Kabupaten Majene. Journal of Economic, Public, and Accounting (JEPA), 1(2), 58-67. https://doi.org/10.31605/jepa.v1i2.297

Hamid, S. N. A., \& Jusoh, W. J. W. (2016). Corporate image of zakat institutions in Malaysia. Geografia: Malaysian Journal of Society and Space, 12(2), 47-57.

Hasibuan, H. T. (2016). Statement of Financial Accounting Standard (PSAK) No. 109 and Its Implementation in Several Zakat Management Organizations in Malang, East Java. Shirkah: Journal of Economics and Business, 1(3), 339.

https://doi.org/10.22515/shirkah.v1i3.89

Irti, I. K., \& Susanto, H. (2019). Utilization Of Zakat, Infaq , And Alms ( Zis ) That Is Productive Of Transparency And Accountability In Indonesia. Proceeding Internastional Seminar on Islamic Studies, 1(109), 816-821.

Islam, M. S., \& Salma, U. (2020). The Management of Zakat By Center for Zakat Management ( Czm ): a Malaysian Experience. International Journal of Zakat and Islamic Philanthrophy, 2(1), 184-191.

JAWHAR. (2021). Department of Wakaf, Zakat and Hajj (JAWHAR). http://www.jawhar.gov.my

Kamaruddin, M. I. H. (2018). A Case Study on Waqf Reporting Practices for Governance, Performance and Socio-Economic Impact in Malaysia. International Journal of Management, Accounting and Economics, 5(9), 693-714. http://www.ijmae.com/index.

Kamaruddin, M. I. H., \& Ramli, N. M. (2018). The Impacts of Internal Control Practices on Financial Accountability in Islamic Non-Profit Organizations in Malaysia. International Journal of Economics, Management and Accounting, 26(2), 365-391.

Mansor, N., Jamil, A., \& Bahari, A. (2017). Strengthening Islamic Social Finance Through Integrated Waqf Reporting System. International Conference on Social Sciences, Humanities and Technology, December.

Marzuki, M. M., \& Wahab, E. A. A. (2018). International financial reporting standards and conservatism in the Association of Southeast Asian Nations countries: Evidence from Jurisdiction Corruption Index. Asian Review of Accounting, 26(4), 487-510. https://doi.org/10.1108/ARA-06-2017-0098

Masruki, R., Hussainey, K., \& Aly, D. (2018a). Developing an Accountability Disclosure Index. Management \& Accounting Review ..., 17(1), 1-18.

Masruki, R., Hussainey, K., \& Aly, D. (2018b). Financial Impact on the Accountability of Malaysian State Islamic Religious Councils (SIRC). The Journal of Muamalat and Islamic Finance Research, 15(2), 21-38. https://doi.org/10.33102/jmifr.v15i2.175

Megawati, D., \& Trisnawati, F. (2014). Penerapan PSAK 109 Tentang Akuntansi Zakat dan Infak/Sedekah Pada BAZ Kota Pekanbaru. Jurnal Penelitian Sosial Keagamaan, 17(1), 4059.

Muflihah, R., \& Wahid, N. N. (2019). Analisis Penerapan PSAK No. 109 Pada Lembaga Amil Zakat, Infak dan Shadaqah di Kota Tasikmalaya. Jurnal Akuntansi, 14(109), 13-21.

Murniati, \& Ikhsan, A. E. (2020). Analisis Penerapan Psak 109 Mengenai Akuntansi Zakat dan Infaq/Sedekah Pada Baitul Mal Aceh. Jurnal Ilmiah Mahasiswa Ekonomi Akuntansi, 5(2), 222-228. https://doi.org/10.24815/jimeka.v5i2.15557

Nelson, S. P., Sapingi, R., \& Ahmad, M. (2018). Identifying Disclosure Items for Zakat Institutions. SSRN Electronic Journal. https://doi.org/10.2139/ssrn.3164698 
Nikmatuniayah, Marliyati, \& Lilis A, M. (2017). Effects of Accounting Information Quality, Accountability, and Transparency on Zakat Acceptance. MIMBAR, Jurnal Sosial Dan Pembangunan, 33(1), 62. https://doi.org/10.29313/mimbar.v33i1.2029

Nurhayati, N., Fadilah, S., Iss, A., \& Oktaroza, M. L. (2014). Pengaruh Kualitas Informasi Akuntansi, Akuntabilitas dan Transparansi Pelaporan Keuangan Terhadap Tingkat Penerimaan Dana Zakat pada Badan Amil Zakat (Baz) Di Jawa Barat. Prosiding SNaPP2014 Sosial, Ekonomi, Dan Humaniora.

http://journal.feb.unmul.ac.id/index.php/JIAM/article/view/7601

Pamuncak, M. B., Possumah, B. T., \& Abdul Hamid, Z. (2018). IFRS based Zakat Reporting: Adoption Rational WesternMethod into Institutional Accountability. Ikonomika, 3(1), 17. https://doi.org/10.24042/febi.v3i1.2512

Rahmadani, F., Karamoy, H., \& Afandi, D. (2018). Analisis Penerapan Akuntansi Zakat, Infaq/Sedekah Pada Badan Amil Zakat Nasional Kota Kotamobagu. Going Concern : Jurnal Riset Akuntansi, 14(1), 85-93. https://doi.org/10.32400/gc.13.04.20905.2018

Roslan, N., Arshad, R., \& Pauzi, N. F. M. (2017). Accountability and Governance Reporting by Non-Profit Organizations. SHS Web of Conferences, 36, 00041. https://doi.org/10.1051

Saad, R. A. J., \& Farouk, A. U. (2019). A comprehensive review of barriers to a functional Zakat system in Nigeria: What needs to be done? International Journal of Ethics and Systems, 35(1), 24-42. https://doi.org/10.1108/IJOES-06-2018-0090

Samargandi, N., Tajularifin, S. M., Ghani, E. K., Aziz, A. A., \& Gunardi, A. (2018). Can disclosure practices and stakeholder management influence zakat payers' trust? A malaysian evidence. Business and Economic Horizons, 14(4), 882-893.

https://doi.org/10.15208/beh.2018.60

Sanep, A., Hairunnizam, W., \& Adnan, M. (2006). Penswastaan Institusi Zakat dan Kesannya Terhadap Pembayaran Secara Formal di Malaysia. International Journal of Management Studies (IJMS), 13(2), 175-196.

Sapingi, R., \& Nelson, S. P. (2016). Current disclosure practices by Zakat Institutions in Malaysia: An exploratory study. 2nd UUM Qualitative Research Conference 2016, May. http://irep.iium.edu.my/58619/

Sarif, S. M., Zakariyah, L. N., \& Noor, A. M. (2015). Financial Reporting in Tabung Masjid Management Driven by in Malaysia. The Islamic Quarterly, 62(1), 103-124.

Shahnaz, S. (2015). Penerapan Psak No.109 Tentang Pelaporan Keuangan Akuntansi Zakat, Infaq/Sedekah Pada Badan Amil Zakat Provinsi Sulawesi Utara. Jurnal Riset Ekonomi, Manajemen, Bisnis, Dan Akuntansi, 3(4), 315-324.

Sudirman, M., Zaenal, M. H., \& Pramono, S. E. (2019). Zakat, Accounting of Zakat, SAK Design of Zakat Accounting Guidelines Based on Comparative Analysis of PSAK 109 and FAS (9) AAOIFI". International Conference of Zakat, 9, 216-231. https://doi.org/10.37706/ iconz.2019.179

Taha, R., Adam, F., Ali, N. N. M., \& Ariff, A. M. (2017). Religiosity and Transparency in the Management of Zakat Institutions. Journal of Legal, Ethical and Regulatory Issues, 20(1), $1-$

Taha, R., Ali, N. N. M., Zulkifli, M. F., \& Nor Paizin, M. (2015). Disclosure of Zakat Information: Is It Important? Proceeding of the International Conference on Masjid, Zakat and Waqf (IMAF 2015), December 2015, 1-7.

Zakariyah, L. N., Ibrahim, A. B., Nor, N. M., Sarif, S. M., \& Noor, A. M. (2016). Maqasid based approach on the role of Muslim public funds in sustaining Islamic microfinance: A case study of Tabung Masjid in Selangor, Malaysia. 11th International Conference on Islamic 
INTERNATIONAL JOURNAL OF ACADEMIC RESEARCH IN BUSINESS AND SOCIAL SCIENCES Vol. 12, No. 1, 2022, E-ISSN: 2222-6990 @ 2022 HRMARS

Economics and Finance, December 2017, 1-29. http://irep.iium.edu.my/52846/ 